\title{
Serratia nematodiphila sp. nov., associated symbiotically with the entomopathogenic nematode Heterorhabditidoides chongmingensis (Rhabditida: Rhabditidae)
}

\author{
Correspondence \\ Ke-Yun Zhang \\ keyunzhang@njau.edu.cn \\ Ren Lai \\ rlai72@njau.edu.cn
}

\author{
Chong-Xing Zhang, ${ }^{1,2,3}$ † Shou-Yun Yang, ${ }^{1,2,3}$ † Ming-Xu Xu, ${ }^{1,2,3} \dagger$ Jie Sun, ${ }^{1}$ \\ Huan Liu, ${ }^{3}$ Jing-Rui Liu, ${ }^{1}$ Hui Liu, ${ }^{1,2}$ Fei Kan, ${ }^{1}$ Jing Sun, ${ }^{1}$ Ren Lai ${ }^{1,3}$ \\ and Ke-Yun Zhang ${ }^{1,2,3}$
}
${ }^{1}$ College of Life Sciences, Nanjing Agricultural University, Nanjing, Jiangsu 210095, PR China
${ }^{2}$ Key Laboratory of Monitoring and Management of Crop Diseases and Pest Insects, Ministry of Agriculture, Nanjing Agricultural University, Nanjing, Jiangsu 210095, PR China
${ }^{3}$ Key Laboratory of Microbiological Engineering of Agricultural Environment, Ministry of Agriculture, Life Sciences College of Nanjing Agricultural University, Nanjing, Jiangsu 210095, PR China

\begin{abstract}
A novel red-pigmented, Gram-negative, motile, fluorescent, rod-shaped strain, $\mathrm{DZ0503SBS1}^{\top}$, with a single lateral flagellum, was isolated from the intestine of the nematode Heterorhabditidoides chongmingensis. Comparative 16S rRNA gene sequence analysis indicated that the strain is a member of the genus Serratia, sharing highest sequence similarities with Serratia marcescens subsp. sakuensis JCM $11315^{\top}(99.8 \%)$, S. marcescens subsp. marcescens DSM $30121^{\top}(99.5 \%)$ and Serratia ureilytica LMG $22860^{\top}(98.3 \%)$. Similarities between the $r p o B$ gene sequence of strain DZ0503SBS $1^{\top}$ and those of $S$. marcescens subsp. sakuensis JCM $11315^{\top}$, S. marcescens subsp. marcescens DSM $30121^{\top}$ and S. ureilytica LMG $22860^{\top}$ were 98.0, 97.4 and $98.3 \%$, respectively. DNA-DNA hybridization values of strain DZ0503SBS $1^{\top}$ with $S$. marcescens subsp. sakuensis JCM $11315^{\top}$, S. marcescens subsp. marcescens DSM $30121^{\top}$ and S. ureilytica LMG $22860^{\top}$ were $68.2,65.1$ and $53.0 \%$, respectively. The major isoprenoid quinone of strain DZ0503SBS $1^{\top}$ was $\mathrm{Q}-8$ and the predominant fatty acids were $\mathrm{C}_{16: 0}(34.76 \%)$, cyclo- $\mathrm{C}_{17: 0}(20.03 \%)$ and cyclo- $\mathrm{C}_{19: 0} \omega 8 \mathrm{c}$ (17.24\%). The cyclo- $\mathrm{C}_{19: 0} \mathrm{o} 8 \mathrm{c}$ content (17.24\%) was significantly different from those found in S. marcescens subsp. sakuensis JCM $11315^{\top}$ and S. marcescens subsp. marcescens DSM $30121^{\top}$. Some characteristics of strain DZ0503SBS1 ${ }^{\top}$, i.e. fluorescence and its symbiotic association with nematodes, have not been reported previously in any species of the genus Serratia. Phenotypic and biochemical characteristics and molecular data show that strain DZ0503SBS $1^{\top}$ represents a novel species, for which the name Serratia nematodiphila sp. nov. is

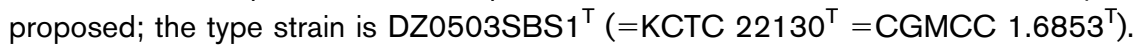

The genus Serratia belongs to the family Enterobacteriaceae of the class Gammaproteobacteria. Some members of the genus Serratia have clinical importance (Grimont \&

†These authors contributed equally to this work.

The GenBank/EMBL/DDBJ accession number for the 16S rRNA gene sequence of strain DZ0503SBS1 ${ }^{\top}$ is EU036987.

A neighbour-joining phylogenetic tree based on partial rpoB gene sequences, a fluorescence micrograph showing the location of strain DZ0503SBS $1^{\top}$ in the intestine of the nematode Heterorhabditidoides chongmingensis, a transmission electron micrograph of strain DZ0503SBS1 ${ }^{\top}$, cellular fatty acid composition data and similarity coefficient values of strain DZ0503SBS1 ${ }^{\top}$ and related taxa are available with the online version of this paper.
Grimont, 1992; Brenner, 1984) and other members produce pigments identified as prodigiosin (Hearn et al., 1970; Gerber, 1975). A subspecies of Serratia marcescens ( $S$. marcescens subsp. sakuensis) and a urea-dissolving species (Serratia ureilytica) have been described previously by Ajithkumar et al. (2003) and Bhadra et al. (2005), respectively. In this paper, a red-pigmented, non-sporeforming, fluorescent strain, designated DZ0503SBS1 ${ }^{\mathrm{T}}$, was isolated from the intestine of the nematode Heterorhabditidoides chongmingensis (Zhang et al., 2008).

The novel strain was associated symbiotically with the entomopathogenic nematode $H$. chongmingensis (Rhabdi- 
tida: Rhabditidae) (Zhang et al., 2008) and was obtained from the infective stages of $H$. chongmingensis by two methods. The first method was to crush approximately 100 surface-disinfected infective juveniles, followed by streaking the products on nutrient bromothymol blue agar (NBTA) plates (Akhurst, 1980). The second method was to streak onto NBTA plates a drop of haemolymph harvested from insects parasitized for $24-48 \mathrm{~h}$ by $\mathrm{H}$. chongmingensis (Bonifassi et al., 1999). To observe the location of the strain in the nematode intestine, 100 adults and 100 infective juveniles of $H$. chongmingensis were selected randomly and collected in a $1.5 \mathrm{ml}$ Eppendorf tube; the nematodes were rinsed three times with Ringer's solution $[6 \mathrm{~g} \mathrm{NaCl}, 0.075 \mathrm{~g}$ $\mathrm{KCl}, 0.1 \mathrm{~g} \mathrm{CaCl}_{2}$ and $\left.0.1 \mathrm{~g} \mathrm{NaHCO}_{3}\left(\mathrm{l} \mathrm{H}_{2} \mathrm{O}\right)^{-1}\right]$, placed onto slides, covered with a coverslip and then examined live under a fluorescence microscope (Axio Imager A1 microscope; Carl Zeiss).

Genomic DNA used for amplification was extracted from cells grown at $30{ }^{\circ} \mathrm{C}$ overnight in TYB agar $(0.3 \%$ yeast extract, $0.2 \%$ beef extract, $0.6 \%$ tryptone, $0.3 \% \mathrm{NaCl}$, $0.001 \% \mathrm{FeCl}_{3}$ and $1.5 \%$ agar) and purified as described previously (Wilson, 2001). The primers used for PCR amplification of the $16 \mathrm{~S}$ rRNA gene were $5^{\prime}$ AGAGTTTGATCCTGGCTCAG-3' (forward) and $5^{\prime}$ AAGGAGGTGATCCAAGCCGCA-3' (reverse), corresponding to positions $8-27$ and $1521-1540$ in the $16 \mathrm{~S}$ rRNA gene sequence of Escherichia coli (Brosius et al., 1978). The resultant sequence (1500 bp) of strain DZ0503SBS1 ${ }^{\mathrm{T}}$ was compared with those in GenBank by using the program BLASTN (Altschul et al., 1997). A phylogenetic tree of related sequences based on BLAST sequence similarity was inferred by using MEGA 3.1 (Kumar et al., 2001) after multiple alignment of the data by CLUSTAL_X (Thompson et al., 1997). Nucleotide sequence similarities and DNA gaps were calculated and edited by using the program BIOEDIT (Hall, 1999). Distances (using distance options according to the Kimura two- parameter model; Kimura, 1980, 1983) and clustering were based on the neighbour-joining method (Saitou \& Nei, 1987). Bootstrap analysis (1000 resamplings) was used to evaluate the topology of the neighbour-joining tree (Felsenstein, 1985). Sequence similarities, based on pairwise sequence comparisons, were investigated by using complete 16S rRNA gene sequences. Comparisons of $16 \mathrm{~S}$ rRNA gene sequences showed that strain DZ0503SBS1 ${ }^{\mathrm{T}}$ should be positioned within the genus Serratia, being related most closely to $S$. marcescens subsp. sakuensis JCM $11315^{\mathrm{T}}$ (99.8\% similarity). The $16 \mathrm{~S}$ rRNA gene sequence similarities of the novel strain with type strains of other established Serratia species were $\leqslant 99.5 \%$ : DZ0503SBS1 ${ }^{\mathrm{T}}$ shared $99.5 \%$ similarity with S. marcescens subsp. marcescens, $98.3 \%$ with S. ureilytica, $97.9 \%$ with Serratia odorifera, $97.9 \%$ with Serratia entomophila, $97.8 \%$ with Serratia ficaria, 96.9\% with Serratia plymuthica, 96.5\% with Serratia grimesii, $96.3 \%$ with Serratia proteamaculans, $96.1 \%$ with Serratia fonticola and $96.1 \%$ with Serratia rubidaea. The phylogenetic tree (Fig. 1) showed that strain DZ0503SBS1 ${ }^{\mathrm{T}}$ was related most closely to $S$. marcescens subsp. sakuensis JCM $11315^{\mathrm{T}}$.

The segment of genomic DNA of strain DZ0503SBS1 ${ }^{\mathrm{T}}$ encoding the RNA polymerase $\beta$-subunit $(r p o B)$ gene, corresponding to positions 1468-2114 of the Escherichia coli $r p o B$ gene, was amplified by a PCR program using primers described by Li et al. (2004). A phylogenetic tree based on $r p o B$ sequences was constructed by using the same method as that for the 16S rRNA gene. The rpoB gene tree showed a similar topology and closer phylogenetic relationship between strain DZ0503SBS1 ${ }^{\mathrm{T}}$ and the three most closely related strains than that constructed by using the 16S rRNA gene (see Supplementary Fig. S1 in IJSEM Online); the closest relative of $\mathrm{DZ0503SBS1}^{\mathrm{T}}$ was $S$. ureilytica LMG $22860^{\mathrm{T}}$ and the two strains formed a sister group of the clade comprising $S$. marcescens subsp. sakuensis JCM $11315^{\mathrm{T}}$ and S. marcescens subsp. marcescens

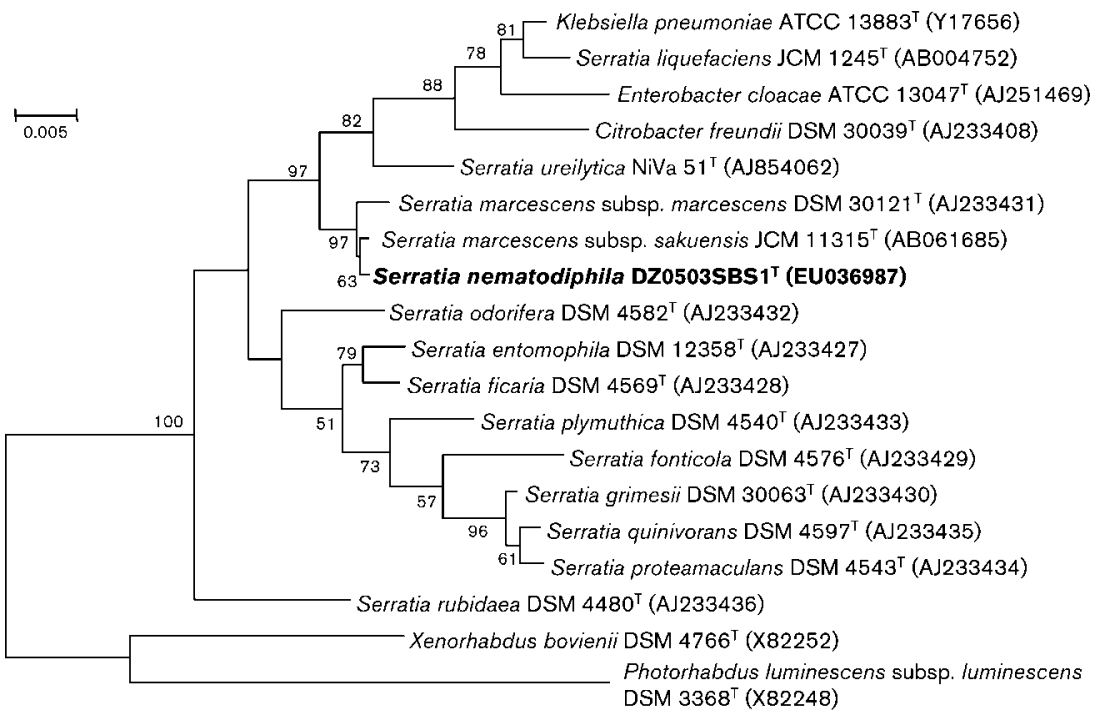

Fig. 1. Phylogenetic position of strain DZ0503SBS $1^{\top}$ among related bacteria in a neighbour-joining tree based on analysis of 16S rRNA gene sequence data. 16S rRNA sequences of representative strains of the genus Serratia and other members of the family Enterobacteriaceae were obtained from GenBank. Bootstrap values (expressed as percentages of 1000 replications) are shown at branch points; only bootstrap values of $50 \%$ and above are shown. Bar, 0.005 substitutions per nucleotide position. 
DSM $30121^{\mathrm{T}}$. The highest level of $r p o B$ sequence similarity was between strain DZ0503SBS1 ${ }^{\mathrm{T}}$ and S. ureilytica LMG $22860^{\mathrm{T}}(98.3 \%)$; strain DZ0503SBS1 ${ }^{\mathrm{T}}$ shared $98.0 \%$ sequence similarity with $S$. marcescens subsp. sakuensis JCM $11315^{\mathrm{T}}$ and $97.4 \%$ similarity with S. marcescens subsp. marcescens DSM 30121 ${ }^{\mathrm{T}}$. Accordingly, 98-100\% intraspecies similarity was observed among enteric strains, whereas 2.0-21.9\% interspecies difference was found (Mollet et al., 1997; Li et al., 2004).

Morphological features were examined by light microscopy and transmission electron microscopy (7650; Hitachi) as described by Nedashkovskaya et al. (2005). Growth was assessed at $4,5,10,25,30,35,37$ and $42{ }^{\circ} \mathrm{C}$ on NBTA and TYB agar media. $\mathrm{NaCl}$ and $\mathrm{pH}$ tolerance were tested by using NBTA and TYB broth containing $0,1,2,3,5,6,7$ and $8 \% \mathrm{NaCl}$ and adjusted to $\mathrm{pH} 2.0-12.0$ (in increments of $1 \mathrm{pH}$ unit) according to Zhou et al. (2007). Growth was evaluated on cetrimide agar, Simmons' citrate agar, trypticase soy agar, MacConkey agar and nutrient agar. All media were incubated at $30{ }^{\circ} \mathrm{C}$ for 2 days. Gram staining, endospore staining and flagellum staining were performed according to the methods described by Smibert \& Krieg (1994). Oxidase activity was tested by determining the oxidation of $1 \%(\mathrm{w} / \mathrm{v})$ tetramethyl-p-phenylenediamine (Merck) and catalase activity was evaluated by determining the production of oxygen bubbles in a $5 \%$ $(\mathrm{v} / \mathrm{v})$ aqueous hydrogen peroxide solution. Acid production from carbohydrates was determined by using the medium and method described by Yamaguchi \& Yokoe (2000). Carbon-source utilization was assessed by using a slightly modified ammonium salt medium $\left[0.2 \% \quad\left(\mathrm{NH}_{4}\right)_{2} \mathrm{SO}_{4}, \quad 0.05 \% \quad \mathrm{NaH}_{2} \mathrm{PO}_{4} . \mathrm{H}_{2} \mathrm{O}, \quad 0.02 \%\right.$ $\mathrm{MgSO}_{4} \cdot 7 \mathrm{H}_{2} \mathrm{O}, 0.01 \% \mathrm{CaCl}_{2} \cdot 2 \mathrm{H}_{2} \mathrm{O}$ and $\left.0.05 \% \mathrm{~K}_{2} \mathrm{HPO}_{4}\right]$ containing $1 \%$ carbon source. Hydrolysis of agar, Tween 80, Tween 20 and CM-cellulose was investigated on NBTA and TYB agar after 2 days incubation according to Lányí (1987) and Smibert \& Krieg (1994). Urease activity and hydrolysis of casein, gelatin, aesculin, tyrosine and starch were determined on NBTA and TYB agar as described by Cowan \& Steel (1965). Nitrate reduction was determined according to the method of Lányí (1987). Antibioticsensitivity tests were performed by using the diffusion method, as described by Park et al. (2007), on NBTA and TYB agar at $30{ }^{\circ} \mathrm{C}$ with filter-paper discs $(8 \mathrm{~mm}$ diameter; Sanofi Pasteur) containing the following antibiotics (in $\mu \mathrm{g}$, unless otherwise indicated): streptomycin (10), penicillin G (10 IU), ampicillin (10), chloramphenicol (30), erythromycin (15), tetracycline (30), ofloxacin (5), amoxicillin (10), cefamezin (30), rifampicin (5), gentamicin (10), ceftazidime (30), vancomycin (30), kanamycin (30), carbenicillin (100) and polymyxin B (30). After 2 days incubation, the diameters of the inhibition zones were measured. Phenotypic characteristics of strain DZ0503SBS1 ${ }^{\mathrm{T}}$ are given in the species description and in Table 1.

Isoprenoid quinone analysis was performed according to Komagata \& Suzuki (1987) using cells harvested from NG agar $\left(1^{-1}: 8.0 \mathrm{~g}\right.$ nutrient broth, $8.0 \mathrm{~g}$ glucose, $5.0 \mathrm{~g} \mathrm{NaCl}$, $0.5 \mathrm{~g}$ yeast extract and $15 \mathrm{~g}$ agar) as described by Ajithkumar et al. (2003). The major isoprenoid quinone was Q-8, which is consistent with that reported previously for the type strain of $S$. marcescens (Grimont \& Grimont, 1992; Collins \& Jones, 1981; Hiraishi, 1999). For quantitative analysis of the cellular fatty acid composition, a loopful of cell mass was harvested from an NG agar plate incubated at $30{ }^{\circ} \mathrm{C}$ for 2 days and fatty acid methyl esters were prepared and identified by following the instructions of the Microbial Identification system (MIDI), as described by Sasser (1990). The major fatty acids found in strain DZ0503SBS1 ${ }^{\mathrm{T}}$ and the type strains of phylogenetically related Serratia species are listed in Supplementary Table S1 (available in IJSEM Online). The major cellular fatty acid in strain DZ0503SBS1 ${ }^{\mathrm{T}}$ was $\mathrm{C}_{16: 0}$, which is in agreement with the profiles of most Serratia species.

Genomic DNA was extracted and purified according to Yoon et al. (1996) and the DNA G+C content was determined by using the thermal-denaturation method (Mandel \& Marmur, 1968). The DNA G $+\mathrm{C}$ content of strain DZ0503SBS1 ${ }^{\mathrm{T}}$ was $59.52 \mathrm{~mol} \%$. This value is higher than that of S. marcescens subsp. sakuensis JCM $11315^{\mathrm{T}}$ (58 mol\%; Ajithkumar et al., 2003), but similar to that of S. marcescens subsp. marcescens DSM $30121^{\mathrm{T}}$ (57.560.0 mol\%; Grimont \& Grimont, 1992; Brenner, 1984).

DNA-DNA hybridizations were determined fluorometrically by the method of Ezaki et al. (1989) using photobiotin-labelled DNA probes and microdilution wells. DNA-DNA hybridization of strain DZ0503SBS1 ${ }^{\mathrm{T}}$ with $S$. marcescens subsp. sakuensis JCM $11315^{\mathrm{T}}$, S. marcescens subsp. marcescens DSM $30121^{\mathrm{T}}$ and S. ureilytica LMG $22860^{\mathrm{T}}$ revealed relatedness values of $68.2,65.1$ and $53.0 \%$, respectively. This indicated that strain DZ0503SBS1 ${ }^{\mathrm{T}}$ represents a novel species of the genus Serratia, according to the criteria used for the delineation of bacterial species (Wayne et al., 1987).

Hence, phenotypic and phylogenetic data support the description of strain DZ0503SBS1 ${ }^{\mathrm{T}}$ as a novel species within the genus Serratia. The novel species can be differentiated from $S$. marcescens subsp. sakuensis based on phenotypic characteristics, such as arginine dihydrolase activity, growth in the presence of D-lactose, D-arabinose, raffinose, D-xylose, melibiose, lactate, L-ornithine, L-proline and L-hydroxyproline as sole carbon sources, and the inability to use oxalate as sole carbon source (Table 1). Proportions of the fatty acids cyclo- $\mathrm{C}_{17: 0}, \mathrm{C}_{14: 0}$ and cyclo$\mathrm{C}_{19: 0} 008 \mathrm{c}$ in DZ0503SBS1 ${ }^{\mathrm{T}}$ were significantly different from those in S. marcescens subsp. sakuensis (see Supplementary Table S1 in IJSEM Online). Strain DZ0503SBS1 ${ }^{\mathrm{T}}$ yielded a maximum similarity coefficient $\left(S_{\mathrm{SM}}\right.$ of 0.82$)$ with $S$. marcescens subsp. marcescens DSM $30121^{\mathrm{T}}$ (see Supplementary Table S2 in IJSEM Online). The fluorescence and symbiotic association with $H$. chongmingensis (Rhabditida: Rhabditidae) (see Supplementary Fig. S2 in IJSEM Online) of strain DZ0503SBS1 ${ }^{\mathrm{T}}$ have not been 
Table 1. Biochemical and physiological characteristics of strain DZ0503SBS1 ${ }^{\top}$ and related taxa

Taxa: 1, DZ0503SBS1 ${ }^{\mathrm{T}}$ (=KCTC 22130 ${ }^{\mathrm{T}}$ ) (this study); 2, S. marcescens subsp. sakuensis JCM 11315 ${ }^{\mathrm{T}}$ (Ajithkumar et al., 2003; this study); 3, S. marcescens subsp. marcescens LMG $2792^{\mathrm{T}}$ (Grimont \& Grimont, 1992); 4, S. ureilytica LMG $22860^{\mathrm{T}}$ (Bhadra et al., 2005); 5, S. odorifera ICPB 3995 (Grimont et al., 1978); 6, S. rubidaea JCM 1240 (Grimont \& Grimont, 1992); 7, S. entomophila ATCC 43705 ${ }^{\mathrm{T}}$ (Grimont et al., 1988); 8, S. liquefaciens ATCC $27592^{\mathrm{T}}$ (Grimont et al., 1982); 9, S. grimesii ATCC $14460^{\mathrm{T}}$ (Grimont et al., 1982); 10, S. plymuthica JCM $1244^{\mathrm{T}}$ (Spröer et al., 1999); 11, S. quinivorans DSM $4597^{\mathrm{T}}$ (Ashelford et al., 2002); 12, S. proteamaculans DSM $4543^{\mathrm{T}}$ (Grimont et al., 1982); 13, S. fonticola DSM 4576 ${ }^{\mathrm{T}}$ (Gavini et al., 1979); 14, S. ficaria DSM $4569^{\mathrm{T}}$ (Grimont et al., 1979). All strains were oxidase-negative, catalase-positive, rod-shaped and motile and could grow in the presence of $8 \% \mathrm{NaCl}$. None of the strains was able to produce indole or $\mathrm{H}_{2} \mathrm{~S}$. All strains were positive for the Voges-Proskauer reaction, aesculin hydrolysis, lysine and ornithine decarboxylase, Simmons' citrate and nitrate reduction. All can utilize succinate, L-arginine and Lhistidine as sole carbon source and produce acids from glucose and sucrose. +, Positive; -, negative; NA, data not available.

\begin{tabular}{|c|c|c|c|c|c|c|c|c|c|c|c|c|c|c|}
\hline Characteristic & 1 & 2 & 3 & 4 & 5 & 6 & 7 & 8 & 9 & 10 & 11 & 12 & 13 & 14 \\
\hline Fluorescence & + & + & - & - & - & - & NA & $\mathrm{NA}$ & - & + & NA & NA & NA & NA \\
\hline Spore formation & - & + & - & - & - & - & - & - & - & - & - & - & - & - \\
\hline Pigment production & + & - & + & - & - & + & - & - & - & + & - & - & + & - \\
\hline Methyl red test & - & - & - & + & + & - & - & + & + & + & - & - & + & + \\
\hline Caseinase & + & + & - & + & - & - & + & + & + & + & + & + & - & - \\
\hline Urease & - & - & - & + & - & - & - & - & - & - & - & - & - & - \\
\hline Lipase (Tween 80) & + & + & + & + & - & + & + & + & + & + & + & + & + & + \\
\hline Arginine dihydrolase & + & - & - & + & - & - & - & - & + & - & - & - & - & - \\
\hline \multicolumn{15}{|l|}{ Utilization of carbohydrates: } \\
\hline Adonitol & + & + & - & + & - & + & + & - & - & - & - & - & + & + \\
\hline D-Lactose & + & - & - & - & + & + & - & - & - & + & - & - & + & + \\
\hline D-Arabinose & + & - & - & - & + & + & - & - & - & - & - & - & - & - \\
\hline Raffinose & + & - & - & - & + & + & - & + & - & + & + & + & + & + \\
\hline D-Xylose & + & - & - & + & + & + & - & + & + & + & + & + & + & + \\
\hline Melibiose & + & - & - & + & + & + & - & + & + & + & + & + & + & + \\
\hline Juranose & + & - & + & + & + & + & + & + & + & + & + & + & + & + \\
\hline \multicolumn{15}{|l|}{ Utilization of organic salts: } \\
\hline Oxalate & - & + & - & + & - & - & $\mathrm{NA}$ & - & - & - & - & - & - & - \\
\hline Lactate & + & - & + & + & + & + & + & + & + & + & + & + & + & + \\
\hline \multicolumn{15}{|l|}{ Amino acid utilization: } \\
\hline D-Serine & + & + & + & + & - & - & - & - & + & + & - & - & NA & NA \\
\hline L-Ornithine & + & - & + & + & + & - & - & + & + & + & + & + & + & + \\
\hline Alanine & + & + & + & + & + & - & + & + & + & + & + & + & + & + \\
\hline L-Proline & + & - & + & + & + & + & + & + & + & + & + & + & + & + \\
\hline Threonine & - & - & - & + & - & - & $\mathrm{NA}$ & - & - & - & - & - & - & - \\
\hline Phenylalanine & - & - & + & + & - & - & - & $\mathrm{NA}$ & - & - & NA & NA & - & - \\
\hline L-Hydroxyproline & + & - & + & + & + & - & NA & $\mathrm{NA}$ & - & - & + & - & $\mathrm{NA}$ & NA \\
\hline L-Tryptophan & + & + & + & - & + & + & - & + & + & - & + & + & $\mathrm{NA}$ & $\mathrm{NA}$ \\
\hline DNA G $+C$ content $(\mathrm{mol} \%)$ & 59.52 & 58 & $57.5-60.0$ & 60 & $\mathrm{NA}$ & NA & 58 & 51.9 & $\mathrm{NA}$ & NA & $53-54$ & $\mathrm{NA}$ & 51.5 & 59.6 \\
\hline
\end{tabular}

reported previously in any species of the genus Serratia. The above data and the physiological characteristics (Table 1) provide decisive evidence that strain DZ0503SBS1 ${ }^{\mathrm{T}}$ is a member of a different genomic species and, therefore, support its classification as a novel species of the genus Serratia, for which the name Serratia nematodiphila sp. nov. is proposed.

\section{Description of Serratia nematodiphila sp. nov.}

Serratia nematodiphila (ne.ma.to.di'phi.la. N.L. n. nematodum nematode; Gr. adj. philos loving; N.L. fem. adj. nematodiphila nematode-loving, referring to its living in the intestine of the nematode Heterorhabditidoides chongmingensis).
Cells are Gram-negative, short rods, $0.8-1.3 \times 0.6-0.7 \mu \mathrm{m}$ (transmission electron micrographs of cells are given in Supplementary Fig. S3, available in IJSEM Online). Aerobic. Possesses a single flagellum. Motile. Colonies on nutrient agar are red, circular and smooth with entire margins. Grows at $4-42{ }^{\circ} \mathrm{C}$ (optimum, $30-37{ }^{\circ} \mathrm{C}$ ), $\mathrm{pH} 5$ 11 (optimum, $\mathrm{pH} 6.0-10.0$ ) and 2-7\% NaCl. Growth occurs on trypticase soy agar, nutrient agar, cetrimide agar, Simmons' citrate agar and MacConkey agar. Catalasepositive and oxidase-negative. $\beta$-Galactosidase, ornithine decarboxylase, lysine decarboxylase, arginine dihydrolase and DNase activities are present. Produces amylase. Methyl $\alpha$-D-glucosidase is present, but phenylalanine decarboxylase, arginine decarboxylase and urease activities are absent. Nitrate is not reduced. Negative for indole and 
$\mathrm{H}_{2} \mathrm{~S}$ production and the methyl red test, but the VogesProskauer reaction is positive. Starch, Tween 80 , casein, gelatin and Tween 20 are hydrolysed, but cellulose is not hydrolysed. Acid is produced from maltose, D-fructose, Dglucose, sucrose, salicin, L-fucose, D-ribose, xylitol, Dmannose, inositol, D-mannitol, D-galactose and D-sorbitol, but not from D-xylose, D-lactose, starch, diarabinose, Drhamnose, L-sorbose, raffinose, L-arabitol, cellobiose, adonite, melezitose, melibiose, amygdalin or D-erythrose. Utilizes adonitol, D-xylose, maltose, D-arabinose, D-fructose, D-glucose, D-lactose, sucrose, D-erythrose, starch, diarabinose, salicin, L-fucose, raffinose, L-arabitol, cellobiose, D-ribose, D-sorbitol, xylitol, D-mannose, inositol, adonite, melezitose, melibiose, D-mannitol, D-galactose, juranose, amygdalin, erythritol, dextrin, inulin and citrate, but does not utilize acetate, malonate, tartrate or sodium pyruvate. Whole-cell fatty acids are $\mathrm{C}_{16: 0}$, cyclo- $\mathrm{C}_{17: 0}$, cyclo- $\mathrm{C}_{19: 0} \omega 8 c, \mathrm{C}_{14: 0}, \mathrm{C}_{12: 0}, \mathrm{C}_{18: 1} \omega 7 c, \mathrm{C}_{14: 0} 2-\mathrm{OH}$ and traces $(<1 \%)$ of $\mathrm{C}_{18: 0}, \mathrm{C}_{10: 0} 3-\mathrm{OH}$, iso- $\mathrm{C}_{19: 0}, \mathrm{C}_{15: 0}, \mathrm{C}_{12: 0}$ 2-OH, $\mathrm{C}_{12: 0}$ 3-OH, unknown (ECL 14.502), summed feature 2 and summed feature 3. Resistant to ceftazidime and vancomycin, but sensitive to gentamicin, streptomycin, kanamycin, penicillin G, ampicillin, chloramphenicol, erythromycin, tetracycline, ofloxacin, amoxicillin, cefamezin, rifampicin, carbenicillin and polymyxin $\mathrm{B}$. The DNA $\mathrm{G}+\mathrm{C}$ content of the type strain is $59.52 \mathrm{~mol} \%$.

The type strain is DZ0503SBS1 ${ }^{\mathrm{T}} \quad\left(=\mathrm{KCTC} 22130^{\mathrm{T}}\right.$ $=$ CGMCC $1.6853^{\mathrm{T}}$ ), isolated from the intestine of $H$. chongmingensis (Rhabditida: Rhabditidae). Experimental support in favour of symbiosis has been demonstrated by Zhang et al. (2008).

\section{Acknowledgements}

This work was supported by the Jiangsu Natural Science Foundation (BK2006560), the China Post-doctoral Science Foundation (20060390292) and the Jiangsu Post-doctoral Science Foundation (0601030B).

\section{References}

Ajithkumar, B., Ajithkumar, V. P., Iriye, R., Doi, Y. \& Sakai, T. (2003). Spore-forming Serratia marcescens subsp. sakuensis subsp. nov., isolated from a domestic wastewater treatment tank. Int J Syst Evol Microbiol 53, 253-258.

Akhurst, R. J. (1980). Morphological and functional dimorphism in Xenorhabdus spp., bacteria symbiotically associated with the insect pathogenic nematodes Neoaplectana and Heterorhabditis. J Gen Microbiol 121, 303-309.

Altschul, S. F., Madden, T. L., Schäffer, A. A., Zhang, J., Zhang, Z., Miller, W. \& Lipman, D. J. (1997). Gapped BLAST and PSI-BLAST: a new generation of protein database search programs. Nucleic Acids Res 25, 3389-3402.

Ashelford, K. E., Fry, J. C., Bailey, M. J. \& Day, M. J. (2002). Characterization of Serratia isolates from soil, ecological implications and transfer of Serratia proteamaculans subsp. quinovora Grimont et al. 1983 to Serratia quinivorans corrig., sp. nov. Int J Syst Evol Microbiol 52, 2281-2289.
Bhadra, B., Roy, P. \& Chakraborty, R. (2005). Serratia ureilytica sp. nov., a novel urea-utilizing species. Int J Syst Evol Microbiol 55, 21552158.

Bonifassi, E., Fischer-Le Saux, M., Boemare, N. E., Lanois, A., Laumond, C. \& Smart, G. (1999). Gnotobiological study of infective juveniles and symbionts of Steinernema scapterisci: a model to clarify the concept of the natural occurrence of monoxenic associations in entomopathogenic nematodes. J Invertebr Pathol 74, 164-172.

Brenner, D. J. (1984). Family I. Enterobacteriaceae Rahn 1937, Nom. Fam. Cons. Opin. 15, Jud. Comm. 1958, 73; Ewing, Farmer and Brenner 1980, 674; Judicial Commission 1981, 104. In Bergey's Manual of Systematic Bacteriology, vol. 1, pp. 408-420. Edited by N. R. Krieg \& J. G. Holt. Baltimore, MD: Williams \& Wilkins.

Brosius, J., Palmer, M. L., Kennedy, P. J. \& Noller, H. F. (1978). Complete nucleotide sequence of $16 \mathrm{~S}$ ribosomal RNA gene from Escherichia coli. Proc Natl Acad Sci U S A 75, 4801-4805.

Collins, M. D. \& Jones, D. (1981). Distribution of isoprenoid quinone structural types in bacteria and their taxonomic implication. Microbiol Rev 45, 316-354.

Cowan, S. T. \& Steel, K. J. (1965). Manual for the Identification of Medical Bacteria. London: Cambridge University Press.

Ezaki, T., Hashimoto, Y. \& Yabuuchi, E. (1989). Fluorometric deoxyribonucleic acid-deoxyribonucleic acid hybridization in microdilution wells as an alternative to membrane filter hybridization in which radioisotopes are used to determine genetic relatedness among bacterial strains. Int J Syst Bacteriol 39, 224-229.

Felsenstein, J. (1985). Confidence limits on phylogenies: an approach using the bootstrap. Evolution 39, 783-791.

Gavini, F., Ferragut, C., Izard, D., Trinel, P. A., Leclerc, H., Lefebvre, B. \& Mossel, D. A. A. (1979). Serratia fonticola, a new species from water. Int J Syst Bacteriol 29, 92-101.

Gerber, N. N. (1975). Prodigiosin-like pigments. CRC Crit Rev Microbiol 3, 469-485.

Grimont, F. \& Grimont, P. A. D. (1992). The genus Serratia. In The Prokaryotes, vol. 3, 2nd edn, pp. 2822-2848. Edited by A. Balows, H. G. Trüper, M. Dworkin, W. Harder \& K. H. Schleifer. New York: Springer.

Grimont, P. A. D., Grimont, F., Richard, C., Davis, B. R., Steigerwalt, A. G. \& Brenner, D. J. (1978). Deoxyribonucleic acid relatedness between Serratia plymuthica and other Serratia species with a description of Serratia odorifera sp. nov. (holotype: ICPB 3995). Int J Syst Bacteriol 28, 453-463.

Grimont, P. A. D., Grimont, F. \& Starr, M. P. (1979). Serratia ficaria sp. nov., a bacterial species associated with Smyrna figs and the fig wasp Blastophaga psenes. Curr Microbiol 2, 277-282.

Grimont, P. A. D., Grimont, F. \& Irino, K. (1982). Biochemical characterization of Serratia liquefaciens sensu stricto, Serratia proteamaculans, and Serratia grimesii sp. nov. Curr Microbiol 7, 69-74.

Grimont, P. A. D., Jackson, T. A., Ageron, E. \& Noonan, M. J. (1988). Serratia entomophila sp. nov. associated with amber disease in the New Zealand grass grub, Costelytra zealandica. Int J Syst Bacteriol 38, $1-6$.

Hall, T. A. (1999). BioEdit: a user-friendly biological sequence alignment editor and analysis program for Windows 95/98/NT. Nucleic Acids Symp Ser 41, 95-98.

Hearn, W. R., Elson, M. K., Williams, R. H. \& Medina-Castro, J. (1970). Prodigiosin [5-(2-pyrryl)-2,2'-dipyrrylmethene] and some substituted prodigiosenes. J Org Chem 35, 142-145.

Hiraishi, A. (1999). Isoprenoid quinones as biomarkers of microbial populations in the environment. J Biosci Bioeng 88, 449-460. 
Kimura, M. (1980). A simple method for estimating evolutionary rates of base substitutions through comparative studies of nucleotide sequences. J Mol Evol 16, 111-120.

Kimura, M. (1983). The Neutral Theory of Molecular Evolution. Cambridge: Cambridge University Press.

Komagata, K. \& Suzuki, K. (1987). Lipid and cell-wall analysis in bacterial systematics. Methods Microbiol 19, 161-207.

Kumar, S., Tamura, K., Jakobsen, I.-B. \& Nei, M. (2001). MEGA2: molecular evolutionary genetics analysis software. Bioinformatics 17, $1244-1245$

Lányí, B. (1987). Classical and rapid identification methods for medically important bacteria. Methods Microbiol 19, 1-67.

Li, X., Zhang, D., Chen, F., Ma, J., Dong, Y. \& Zhang, L. (2004). Klebsiella singaporensis sp. nov., a novel isomaltulose-producing bacterium. Int J Syst Evol Microbiol 54, 2131-2136.

Mandel, M. \& Marmur, J. (1968). Use of ultraviolet absorbancetemperature profile for determining the guanine plus cytosine content of DNA. Methods Enzymol 12B, 195-206.

Mollet, C., Drancourt, M. \& Raoult, D. (1997). $r p o B$ sequence analysis as a novel basis for bacterial identification. Mol Microbiol 26, 10051011.

Nedashkovskaya, O. I., Kim, S. B., Suzuki, M., Shevchenko, L. S., Lee, M. S., Lee, K. H., Park, M. S., Frolova, G. M., Oh, H. W. \& other authors (2005). Pontibacter actiniarum gen. nov., sp. nov., a novel member of the phylum 'Bacteroidetes', and proposal of Reichenbachiella gen. nov. as a replacement for the illegitimate prokaryotic generic name Reichenbachia Nedashkovskaya et al. 2003. Int J Syst Evol Microbiol 55, 2583-2588.

Park, M., Ryu, S. H., Thi Vu, T.-H., Ro, H.-S., Yun, P.-Y. \& Jeon, C. O. (2007). Flavobacterium defluvii sp. nov., isolated from activated sludge. Int J Syst Evol Microbiol 57, 233-237.

Saitou, N. \& Nei, M. (1987). The neighbour-joining method: a new method for reconstructing phylogenetic trees. Mol Biol Evol 4, 406-425.

Sasser, M. (1990). Identification of bacteria by gas chromatography of cellular fatty acids. USFCC Newsl 20, 16.
Smibert, R. M. \& Krieg, N. R. (1994). Phenotypic characterization. In Methods for General and Molecular Bacteriology, pp. 607-654. Edited by P. Gerhardt, R. G. E. Murray, W. A. Wood \& N. R. Krieg. Washington, DC: American Society for Microbiology.

Spröer, C., Mendrock, U., Swiderski, J., Lang, E. \& Stackebrandt, E. (1999). The phylogenetic position of Serratia, Buttiauxella and some other genera of the familiy Enterobacteriaceae. Int J Syst Bacteriol 49, $1433-1438$.

Thompson, J. D., Gibson, T. J., Plewniak, F., Jeanmougin, F. \& Higgins, D. G. (1997). The CLUSTAL_X windows interface: flexible strategies for multiple sequence alignment aided by quality analysis tools. Nucleic Acids Res 25, 4876-4882.

Wayne, L. G., Brenner, D. J., Colwell, R. R., Grimont, P. A. D., Kandler, O., Krichevsky, M. I., Moore, L. H., Moore, W. E. C., Murray, R. G. E. \& other authors (1987). International Committee on Systematic Bacteriology. Report of the ad hoc committee on reconciliation of approaches to bacterial systematics. Int J Syst Bacteriol 37, 463-464.

Wilson, K. (2001). Preparation of genomic DNA from bacteria: miniprep of bacterial genomic DNA. In Current Protocols in Molecular Biology, pp. 2.4.1-2.4.2. Edited by F. M. Ausubel, R. Brent, R. E. Kingston, D. D. Moore, J. G. Seidman, J. A. Smith \& K. Struhl. New York: Wiley. doi:10.1002/0471142727.mb0204s56

Yamaguchi, S. \& Yokoe, M. (2000). A novel protein-deamidating enzyme from Chryseobacterium proteolyticum sp. nov., a newly isolated bacterium from soil. Appl Environ Microbiol 66, 3337-3343.

Yoon, J.-H., Kim, H., Kim, S.-B., Kim, H.-J., Kim, W. Y., Lee, S. T., Goodfellow, M. \& Park, Y.-H. (1996). Identification of Saccharomonospora strains by the use of genomic DNA fragments and rRNA gene probes. Int J Syst Bacteriol 46, 502-505.

Zhang, C. X., Liu, J. R., Xu, M. X., Sun, J., Yang, S. Y., An, X., Gao, G. F., Lin, M. S., Lai, R. \& other authors (2008). Heterorhabditidoides chongmingensis gen. nov., sp. nov. (Rhabditida: Rhabditidae), a novel member of the entomopathogenic nematodes. J Invertebr Pathol 98, 153-168.

Zhou, Y., Wang, X., Liu, H., Zhang, K. Y., Zhang, Y. Q., Lai, R. \& Li, W. J. (2007). Pontibacter akesuensis sp. nov., isolated from a desert soil in China. Int J Syst Evol Microbiol 57, 321-325. 